\title{
Upper-room ultraviolet air disinfection might help to reduce COVID-19 transmission in buildings: a feasibility study
}

\author{
Clive B Beggs ${ }^{\text {Equal first author, } 1}$, Eldad J Avital ${ }^{\text {Corresp. Equal first author, } 2}$ \\ ${ }^{1}$ Carnegie School of Sport, Leeds Beckett University, Leeds, United Kingdom \\ 2 School of Engineering and Materials Science, Queen Mary University of London, London, United Kingdom \\ Corresponding Author: Eldad J Avital \\ Email address: e.avital@qmul.ac.uk
}

As the world's economies come out of the lockdown imposed by the COVID-19 pandemic, there is an urgent need for technologies to mitigate COVID-19 transmission in confined spaces such as buildings. This feasibility study looks at one such technology, upper-room ultraviolet (UV) air disinfection, that can be safely used while humans are present in the room space, and which has already proven its efficacy as an intervention to inhibit the transmission of airborne diseases such as measles and tuberculosis. Using published data from various sources, it is shown that the SARS-CoV-2 virus, the causative agent of COVID-19, is highly likely to be susceptible to UV-C damage when suspended in air, with a UV susceptibility constant likely to be in the region $0.377-0.590 \mathrm{~m}^{2} / \mathrm{J}$, similar to that for other aerosolised coronaviruses. As such, the UV-C flux required to disinfect the virus is expected to be acceptable and safe for upper-room applications. Through analysis of expected and worst-case scenarios, the efficacy of the upper-room UV-C approach for reducing COVID-19 transmission in confined spaces (with moderate but sufficient ceiling height) is demonstrated. Furthermore, it is shown that with SARS-CoV-2, it should be possible to achieve high equivalent air change rates using upper-room UV air disinfection, suggesting that the technology might be particularly applicable to poorly ventilated spaces. 
1 Upper-room ultraviolet air disinfection might help to reduce COVID-19 transmission in

2 buildings: a feasibility study

3

4 Clive B. Beggs ${ }^{1}$ and Eldad J. Avital ${ }^{2}$

5

6 1. Carnegie School of Sport, Leeds Beckett University, Leeds, United Kingdom

7

2. School of Engineering and Materials Science, Queen Mary University of London,

11 Corresponding author

12 Eldad Avital

13

14

School of Engineering and Material Science,

15

Queen Mary University of London,

16 Mile End Road,

17 Bethnal Green,

18 London E1 4NS,

19 United Kingdom

20

21

email: e.avital@qmul.ac.uk

22

Both are equal authors

24

25

26

27

28

29

30 


\section{Abstract}

37 As the world's economies come out of the lockdown imposed by the COVID-19 pandemic, there 38 is an urgent need for technologies to mitigate COVID-19 transmission in confined spaces such 39 as buildings. This feasibility study looks at one such technology, upper-room ultraviolet (UV) air 40 disinfection, that can be safely used while humans are present in the room space, and which 41 has already proven its efficacy as an intervention to inhibit the transmission of airborne diseases 42 such as measles and tuberculosis.

43

44 Using published data from various sources, it is shown that the SARS-CoV-2 virus, the 45 causative agent of COVID-19, is highly likely to be susceptible to UV-C damage when 46 suspended in air, with a UV susceptibility constant likely to be in the region $0.377-0.590 \mathrm{~m}^{2} / \mathrm{J}$, similar to that for other aerosolised coronaviruses. As such, the UV-C flux required to disinfect the virus is expected to be acceptable and safe for upper-room applications.

49

Through analysis of expected and worst-case scenarios, the efficacy of the upper-room UV-C approach for reducing COVID-19 transmission in confined spaces (with moderate but sufficient ceiling height) is demonstrated. Furthermore, it is shown that with SARS-CoV-2, it should be possible to achieve high equivalent air change rates using upper-room UV air disinfection, suggesting that the technology might be particularly applicable to poorly ventilated spaces.

\section{Keywords}

58 COVID-19, SARS-CoV-2, ultraviolet, air disinfection, upper-room UV-C, aerosols, droplet-borne 59 disease, indoor air 


\section{Introduction}

71

Since the emergence of COVID-19 in January 2020 there has been considerable interest in the use of ultraviolet (UV) light to disinfect blood plasma (Eickmann et al. 2020; Keil et al. 2020b; Ragan et al. 2020), equipment (Card et al. 2020; Derraik et al. 2020; Hamzavi et al. 2020; Heimbuch \& Harnish 2019) and air (Morawska et al. 2020), in the hope that this might reduce transmission of the disease. In particular, upper-room ultraviolet germicidal irradiation (UVGI), a technology that disinfects room air, has been muted as a potential intervention that might prove effective against COVID-19 (Morawska et al. 2020; Nardell \& Nathavitharana 2020; Skorzewska 2020). Upper-room UVGI utilizes UV-C light at wavelengths close to $254 \mathrm{~nm}$ to create an irradiation field above the heads of room occupants (Figure 1) that disinfects aerosolised bacteria and viruses suspended in the air (Beggs et al. 2006; Beggs \& Sleigh 2002; Noakes et al. 2015). Because UV-C light is harmful to humans, such systems utilize louvres or shields that obscure the UV lamps from eyesight so that room occupants are kept safe. As such, upperroom UVGI is a well-established technology (First et al. 1999a; First et al. 1999b) that has proven effective as a public health intervention to prevent the spread of airborne diseases such as measles (Nardell \& Nathavitharana 2019) and tuberculosis (TB) (Escombe et al. 2009; Mphaphlele et al. 2015) in buildings.

88

Given that COVID-19 can be transmitted by the inhalation of aerosolised respiratory droplets containing the SARS-CoV-2 virus (Beggs 2020; Miller et al. 2020; Morawska et al. 2020; Stadnytskyi et al. 2020), and that several studies have recovered viral RNA from hospital air samples (Chia et al. 2020; Guo et al. 2020; Jiang et al. 2020; Santarpia et al. 2020), there is reason to believe that upper-room UVGI might be effective at 'killing' (inactivating) SARS-CoV-2 virions in the air, thus reducing the transmission of COVID-19 in buildings and other enclosed spaces. However, this presupposes that the technology is capable of delivering irradiation doses high enough to inactivate SARS-CoV-2 virions in respiratory droplets suspended in the air, something that has not yet been proven. Given this and the urgent need to develop interventions to break the chain of infection associated with COVID-19, we designed the short feasibility study reported here with the aim of evaluating whether or not upper-room UVGI might be an effective intervention against COVID-19. 
101

102

103

104

Methods

105

106

\section{Theory}

107

At any point in time the amount of viral inactivation (disinfection) achieved for a given UV radiant flux (irradiance) can be described using the following first order decay equation (McDevitt et al. 109 2012).

$111 N_{t}=N_{0} \times e^{-Z . E . t}$

112

Where: $N_{0}$ and $N_{t}$ are the number of viable viral particles (virions) at time zero and $t$ seconds respectively; $Z$ is the UV susceptibility constant for the virus $\left(\mathrm{m}^{2} / \mathrm{J}\right)$; $E$ is the radiant (irradiation)

115 flux $\left(\mathrm{W} / \mathrm{m}^{2}\right)$; and $t$ is time in seconds.

116

117 The UV irradiation dose received by the virus is simply:

118

$119 H=E \times t$

120

121

Where: $H$ is the observed UV irradiation dose $\left(\mathrm{J} / \mathrm{m}^{2}\right)$.

122

123

By combining equations 1 and 2 , and rearranging we can obtain a value for $Z$.

124

$125 Z=-\frac{1}{H} \times \ln \left(\frac{N_{t}}{N_{0}}\right)=-\frac{1}{H} \times \ln (f)$

126

127

Where: $f$ is the survival fraction.

128

129

Because the relationship between the UV dose and the natural logarithm of the survival fraction

130 is broadly linear for most viral species, it means that the behaviour of any given virus exposed to UV-C light can be succinctly described by the value of $Z$, irrespective of the actual UV dose 132 applied. As such, for any given viral species, if the value of $Z$ is known, then it should be 
133 possible to predict with reasonable accuracy how the virus will behave when exposed to a given

134 UV-C dose in any context. Microbes that exhibit larger $Z$ values are more susceptible to UV

135 damage, whereas those with small $Z$ values are more difficult to inactivate.

136

137 UV inactivation plots for most viral species tend to be straight lines, although some might exhibit 138 a curve (Kariwa et al. 2006). Notwithstanding this, the model described in equation 1 is still a 139 good approximation for most viral species (McDevitt et al. 2012) up until the point where the 140 'target' becomes saturated with UV photons. At this point, because all the virions have already 141 been inactivated, increasing the UV dose further has no effect and so the linear relationship 142 between UV dose and the log reduction become decoupled, with the result that the $Z$ value no 143 long applies.

144

145 Instead of quantifying UV inactivation in terms of survival fraction, many researchers,

146 particularly those working in biology, describe the reduction in the microbial count in terms of log 147 reduction, which can be converted to survival fraction as follows:

148

$149 f=\frac{1}{10^{A}}$

150

151

Where: $A$ is the $\log _{10}$ reduction in the number of virions.

152

153

Specifically, with regard to upper-room UVGI, once the Z value has been obtained for the target

154 microbe, it is then possible to determine the irradiation flux required to disinfect it, using the 155 methodology described in Beggs and Sleigh (Beggs \& Sleigh 2002). This method makes the 156 assumption that the room air is well mixed, which is a reasonable approximation for most 157 applications (Beggs \& Sleigh 2002). If this is the case, then the average particle residence time, 158 $t_{\text {res }}$ (in seconds) in the room space will be:

159

$160 t_{\text {res }}=\frac{1}{n} \times 3600$

161

162 Where: $n$ is the room ventilation rate in air changes per hour (AC/h). 
164 From equation 5 it can be approximated that the average particle residence time in the upper-

165 room UV field, $t_{u v}$, (in seconds) will be:

166

$167 t_{u v}=t_{r e s} \times \frac{h_{u v}}{h_{r}}$

168

169

Where: $h_{r}$ is the floor-to-ceiling height $(\mathrm{m})$, and $h_{u v}$ is the depth of the upper-room UV zone $(\mathrm{m})$

170 (see Figure 1).

171

172 Because $Z$ values are often determined experimentally using microbes suspended in liquids or

173 on surfaces, it may be necessary to adjust the $Z$ value for use with upper-room UVGI systems

174 (Beggs et al. 2006; Yang et al. 2017), as follows:

175

176

$Z_{u r}=Z \times c_{u r}$

177

178

Where: $Z_{u r}$ is the effective upper-room $Z$ value $\left(\mathrm{m}^{2} / \mathrm{J}\right)$, and $c_{u r}$ is a correction coefficient.

179

180

For practical purposes, $Z_{u r}$ can be assumed to be the same as the $Z$ value achieved when a

181 given microbe is irradiated in an aerosol.

182

183

So if we assume that the air in a room is well mixed, by combining equations 2, 3 and 6 it is

184 possible to compute the average irradiation flux, $E_{r}$, that is required to achieve a desired survival 185 fraction, $f_{\mathrm{r}}$.

186

$187 \quad E_{r}=-\frac{1}{\left(z_{u r} \times t_{u v}\right)} \times \ln \left(f_{r}\right)$

188

189

Alternatively, the disinfection achieved by an upper-room UVGI system can be thought of as

190 being equivalent to additional air changes in the room space (McDevitt et al. 2008). In this

191 scenario, the UV rate constant, $k_{u v}$, which can be thought of as the equivalent air change rate

192 per second, can be determined using (Beggs et al. 2006):

193

$194 k_{u v}=Z_{u r} \times E \times \frac{h_{u v}}{h_{r}}$ 
195

196

197

198

199

200

201

202

203

204

205

206

207

208

209

210

211

212

213

214

215

216

217

218

219

220

221

222

223

224

225

226

227

So, in a ventilated room in which contamination ceases at time zero, we can utilize both the UV rate constant, $k_{u v}$, and a rate constant, $k_{v}$, for the ventilation (i.e. $n \div 3600$ ), to produce a decay model for the room space.

$C_{t}=C_{0} \times e^{-\left(k_{v}+k_{u v}+k_{d}\right) t}$

Where; $C_{0}$ and $C_{t}$ are the concentrations of viable viral particles in the room space (virions $/ \mathrm{m}^{3}$ ) at time zero and $t$ seconds respectively; $k_{v}$ is the ventilation rate constant; $k_{d}$ is the particulate deposition rate constant (e.g. $0.0014 \mathrm{~s}^{-1}$ (Stadnytskyi et al. 2020)); and $t$ is time in seconds.

\section{Analysis of published data}

A search of the relevant scientific literature (i.e. published literature, pre-prints and relevant websites) was undertaken to identify published data relating to the UV irradiation of the three closely related coronaviruses: SARS-CoV-2, the causative agent of COVID-19; SARS-CoV-1, the causative agent of severe acute respiratory syndrome (SARS); and MERS-CoV, the causative agent of middle east respiratory syndrome (MERS).

Because the experimental methods used in the various UV studies varied greatly, as did the level of detail reported, it was necessary to adopt a standardized approach so that valid comparisons could be made. It was therefore decided that, rather than estimating the $Z$ value for a nominal log one reduction (i.e. $D_{90}$ ) as others have done (Kowalski 2010), we would instead use the log reduction values and UV doses reported in the various studies to calculate the respective $Z$ values using equation 3 . In so doing, we were able to utilize the results from studies that would otherwise be excluded because the log reductions achieved were far in excess of one. Where researchers performed experiments using a range of UV doses, we calculated the $Z$ value for two UV doses, one near the start of the inactivation process and the other just before the saturation point. So as to avoid bias due to pseudo-replication, when computing the average $Z$ values for the respective viral species, we first aggregated the $Z$ values reported for the various individual studies and then used the aggregated values to calculate the overall mean $Z$ values for the respective viruses. 
In order to compare the $Z$ values for the coronaviruses with those for influenza, we utilized experimental results produced by Heimbuch \& Harnish (Heimbuch \& Harnish 2019) who irradiated coupons of respirator material inoculated with SARS-CoV-1 and MERS-CoV, as well as four strains of influenza A, allowing direct comparisons to be made between the viral species.

\section{Estimating an effective upper-room Z value for aerosolised SARS-CoV-2}

In order to evaluate how SARS-CoV-2 might behave in the presence of UV-C when aerosolised, we reviewed the available literature on the subject (Jensen 1964; Kowalski 2010; Kowalski et al. 2000; McDevitt et al. 2012; Walker \& Ko 2007) with the aim of estimating a value for the coefficient, $c_{u r}$, in equation 7 , which we then used to estimate the effective upper-room $Z$ value, $Z_{\text {ur. }}$ In order to reflect the uncertainty associated with this, we compared effective $Z$ values for aerosolised coronaviruses reported in the literature with values obtained for SARS-CoV-2 in liquids to obtain the range of possible values for $c_{u r}$.

244

\section{Computation of required upper-room UV irradiation flux}

Having estimated the value of $Z_{u r}$ for SARS-CoV-2 from the literature, we then used equations 6 - 90\% reduction in aerosolised SARS-CoV-2 virions (through the action of the UV-C alone) in a chosen because they are typical for an upper-room UVGI installation in which the lamp height is $2.1 \mathrm{~m}$ above the floor (First et al. 1999b). In the model we assumed that the air was completely mixed, which meant that according to equation 6 , aerosol particles would spend on average $16 \%$ of their room residency time in the UV zone.

In addition to computing the required UV flux, we also wanted to know how a standard upperroom UV fitting might perform when challenged by SARS-CoV-2. In accordance with the guidelines stated by First (First et al. 1999b), we assumed that the room contained a single 30 W (input) UV-C fitting capable of delivering an average upper-room flux of $50 \mu \mathrm{W} / \mathrm{cm}^{2}$, and modelled its performance in terms of equivalent ventilation rate using equation 9.

\section{Results}




\section{Analysis of the published literature}

264

265

266

267

268

269

270

271

272

273

274

275

276

277

278

279

280

281

282

283

284

285

286

287

288

289

290

291

292

293

294

295

The results of the literature search are summarized in Table 1, which shows the UV-C (254 nm) doses applied and log reductions achieved in six studies investigating SARS-CoV-1 (Darnell et al. 2004; Darnell \& Taylor 2006; Duan et al. 2003; Eickmann et al. 2020; Heimbuch \& Harnish 2019; Kariwa et al. 2006), two studies investigating MERS-CoV (Bedell et al. 2016; Heimbuch \& Harnish 2019), and two studies investigating SARS-CoV-2 (Bianco et al. 2020; Signify 2020). Table 1 also includes the results of one study that investigated the impact of deep-UV light at $280 \mathrm{~nm}$ (i.e. the boundary between UV-B and UV-C) on SARS-CoV-2 (Inagaki et al. 2020). In addition, three studies were found that used a combination of UV-A and UV-B light (270-360 $\mathrm{nm}$ ), together with the photosensitiser, riboflavin, to disinfect SARS-CoV-2 (Keil et al. 2020b; Ragan et al. 2020) and MERS-CoV (Keil et al. 2020a) in blood products (Table 2). Although these studies did not utilize UV-C light, it was nevertheless decided to report the results of these studies here so that direct comparisons could be made between SARS-CoV-2 and MERS-CoV. The MERS-CoV irradiation study by Bedell et al. (Bedell et al. 2016) is included for completeness, even though the authors did not report the UV dose received by the virus, making it impossible to compute a $Z$ value for this study.

The computed $Z$ values for the respective experiments are shown in Table 3 (UV-C and deepUV) and Table 4 (UV-A/B plus riboflavin). From these it can be seen that the $Z$ values for the MERS-CoV virus were similar in magnitude to those for both SARS-CoV-1 (UV-C) and SARSCoV-2 (UV-A/B). With UV-C irradiation the mean $Z$ value for SARS-CoV-1 was 0.00489 (SD = $0.00611) \mathrm{m}^{2} / \mathrm{J}$, whereas that for MERS-CoV was $0.00104 \mathrm{~m}^{2} / \mathrm{J}$. Likewise, for UV-A/B plus riboflavin the corresponding $Z$ values were $0.00020(S D=0.00009) \mathrm{m}^{2} / \mathrm{J}$ and $0.00016 \mathrm{~m}^{2} / \mathrm{J}$ for SARS-CoV-2 and MERS-CoV respectively. However, by comparison SARS-CoV-2 appeared to be more susceptible to UV damage than either SARS-CoV-1 or MERS-CoV when irradiated with UV-C (mean $\left.Z=0.14141(S D=0.09045) \mathrm{m}^{2} / \mathrm{J}\right)$ and deep-UV light (mean $Z=0.03684$ $\left.\mathrm{m}^{2} / \mathrm{J}\right)$.

The calculated $Z$ values for influenza UV-C irradiation experiments undertaken by Heimbuch \& Harnish (Heimbuch \& Harnish 2019) are presented in Table 5. These experiments, which were carried out using inoculated coupons of respirator material, revealed that in this context the $Z$ values for the various influenza $A$ strains were of the same order of magnitude as those for SARS-CoV-1 and MERS-CoV. 


\section{Effective upper-room Z values for aerosolised SARS-CoV-2}

299

300

301

302

303

304

305

306

307

308

309

310

311

312

313

314

315

316

317

318

319

320

321

322

323

324

325

326

327

328

329

A review of the literature revealed that relatively few experimental studies have been performed involving the UV irradiation of aerosolised viruses, with only three undertaken on a coronavirus (Buonanno et al. 2020; Walker \& Ko 2007). A summary of the findings of several key studies are presented in Table 6, which reveals that most viral species appear to be relatively easy to disinfect when suspended in droplets in the air. In particular, aerosolised viruses appear to be more vulnerable to UV damage than when they are suspended in a liquid or on a substrate. For example, for the 24 irradiation experiments involving adenoviruses suspended in liquid, reported by Kowalski (Kowalski 2010), the average $Z$ value was $0.00586 \mathrm{~m}^{2} / \mathrm{J}$, which is an order of magnitude less than the values of 0.0546 and $0.0390 \mathrm{~m}^{2} / \mathrm{J}$ for aerosolised adenoviruses, attributed to Jensen (Jensen 1964) and Walker and Ko (Walker \& Ko 2007) respectively. Regarding coronaviruses, Walker and Ko (Walker \& Ko 2007) also performed experiments on aerosolised murine (mouse) hepatitis virus (MHV) coronavirus in a single pass test rig. This revealed a $Z$ value of $0.377 \pm 0.119 \mathrm{~m}^{2} / \mathrm{J}$ for this virus. Buonanno et al. (Buonanno et al. 2020) also performed irradiation experiments on aerosolised coronaviruses, but using UV light at 222 $\mathrm{nm}$ (far-UV) rather than $254 \mathrm{~nm}$. They found the $Z$ values for human coronavirus 229E and human coronavirus $0 C 43$ to be $0.410 \mathrm{~m}^{2} / \mathrm{J}$ and $0.590 \mathrm{~m}^{2} / \mathrm{J}$ respectively. Collectively, these $Z$ values are an order of magnitude greater than the values obtained for SARS-CoV-2 in liquid, implying that when aerosolised, coronaviruses in general and SARS-CoV-2 in particular, are much easier to disinfect compared with when they are presented in liquids or on surfaces. Although we are comparing different species of coronavirus here, evidence from Bedell et al. (Bedell et al. 2016), who irradiated MHV coronavirus and MERS-CoV in Petri dishes, suggests that it is nonetheless valid. They found that 5 minutes exposed to a UV-C light source resulted in a 2.71 log reduction for the MHV coronavirus, whereas the same exposure resulted in a 5.91 log reduction for MERS-CoV. This suggests that MHV coronavirus is actually more resistant to UV damage than MERS-CoV, and as such, supports Walker and Ko's (Walker \& Ko 2007) conclusion that coronaviruses are much easier to inactivate in the air compared with on surfaces and in liquids.

Comparing the computed $Z$ values for UV-C irradiation experiments on the MHV coronavirus conducted in air (0.37700 $\mathrm{m}^{2} / \mathrm{J}$ (Walker \& Ko 2007)) with those for the SARS-CoV-2 virus in liquid ranging from $0.06280 \mathrm{~m}^{2} / \mathrm{J}$ (Signify 2020) to $0.20536 \mathrm{~m}^{2} / \mathrm{J}$ (Kariwa et al. 2006), it would 
330

331

332

333

\section{4}

335

336

337

338

339

340

341

342

343

344

345

346

347

348

349

350

351

352

353

354

355

356

357

358

359 360

361

362

appear that irradiating the coronavirus in liquid requires a UV-C dose that is in the region 1.8 6.0 times higher than that required when the virus is suspended in air. From this we estimated that the value of the adjustment coefficient $c_{u r}$ would be in a range $0.167-0.545$.

\section{Upper-room UVGI computation results}

Because no UV irradiation experiments have to date been performed on aerosols containing the SARS-CoV-2 virus, it was necessary when undertaking the feasibility study to make assumptions regarding an appropriate value of $Z_{u r}$ to use in the upper-room UVGI analysis. With respect to this, because the published mean $Z$ values for the aerosolised coronaviruses were all in the region $0.377-0.590 \mathrm{~m}^{2} / \mathrm{J}$, we felt that an assumed $Z$ value in this range would be indicative of how airborne SARS-CoV-2 might behave in a UV-C field. A decision was therefore made to use Walker and Ko's $Z$ value figure of $0.377 \mathrm{~m}^{2} / \mathrm{J}$ to evaluate the expected performance of the upper-room UVGI installation, because this was considered a conservative value. In addition, because of the uncertainty associated with this assumed value, we introduced a 'factor of safety' into our analysis by also modelling a worst-case scenario in which $Z_{u r}$ was $0.0377 \mathrm{~m}^{2} / \mathrm{J}$.

Table 7 presents the results of the room analysis using these two values for $Z_{u r}$, for a range of ventilation rates. From this it can be seen that there is a direct inverse relationship between particle residence time in the UV field, $t_{u v}$, and the required irradiation flux, $E_{r}$, as predicted by equation 8 . This means that for any given $Z$ value, the value of $E_{r}$ will double as the room ventilation rate doubles. The table also reveals that there is a direct inverse relationship between $Z_{u r}$ and $E_{r}$. From the calculated values in this table it can be seen that if $Z_{u r}=0.377$ $\mathrm{m}^{2} / \mathrm{J}$, then with an average UV flux of just $10 \mu \mathrm{W} / \mathrm{cm}^{2}$ it should be possible to achieve $>90 \%$ inactivation of SARS-CoV-2, even at a ventilation rate of $8 \mathrm{AC} / \mathrm{h}$. However, if in reality, $Z_{u r}$, is $0.0377 \mathrm{~m}^{2} / \mathrm{J}$, then all the calculated fluxes would have to increase by a factor of ten to achieve the same results. Given that accepted guidelines (First et al. 1999b) recommend for a room 2.5 $\mathrm{m}$ high, one $30 \mathrm{~W}$ (input) UV lamp per $18.58 \mathrm{~m}^{2}$ of floor area, which will produce an average flux in the region $50 \mu \mathrm{W} / \mathrm{cm}^{2}$, this means that even under this worst-case scenario it should still be possible to achieve disinfection rates $>90 \%$ for all but the highest ventilation rates.

When we fixed the UV flux at an average of $50 \mu \mathrm{W} / \mathrm{cm}^{2}$, we found that for $Z_{u r},=0.377 \mathrm{~m}^{2} / \mathrm{J}$ the upper-room UVGI installation produced an equivalent air change rate of $108.6 \mathrm{AC} / \mathrm{h}$, whereas if 
$363 Z_{u r}=0.0377 \mathrm{~m}^{2} / \mathrm{J}$ this fell to $10.9 \mathrm{AC} / \mathrm{h}$. These values were constant and unaffected by the 364 actual room ventilation rate.

365

366

\section{Discussion}

Analysis of the literature relating to the UV irradiation of coronaviruses clearly reveals that SARS-CoV-2, when in a liquid assay, is relatively easily inactivated by UV light at both $254 \mathrm{~nm}$ (Bianco et al. 2020; Signify 2020) and $280 \mathrm{~nm}$ (Inagaki et al. 2020). Indeed, the results in Table 3 suggest that the virus is likely to be more susceptible to UV-C damage than either SARS-CoV1 or MERS-CoV. Furthermore, the results of the experiments were SARS-CoV-2 was exposed to UV-A/B and riboflavin, suggest that the virus is susceptible to damage, albeit to a lesser extent, caused by UV light at other wavelengths. As such, this appears to support the finding of Sagripanti and Lytle (Sagripanti \& Lytle 2020) that SARS-CoV-2 is vulnerable to sunlight.

375

376

One problem frequently encountered when comparing UV irradiation results from disparate researchers is that experimenters often utilize different methodologies to evaluate log reductions in microbial species, with varying doses of UV administered. In particular, the type of substrate or media used can greatly influence the outcome of the experiment. This is because the substrate or media can absorb the UV photons and shield the virus. Given this, it is important to compare like with like, if this is possible. For this reason we included the results of Heimbuch and Harnish (Heimbuch \& Harnish 2019) in Tables 3 and 5, because they performed the same irradiation experiment on SARS-CoV-1 and MERS-CoV, as well as on four strains of influenza A, thus allowing direct comparisons to be made. From Tables 3 and 5 it can be seen that the $Z$ values for the influenza strains are of a similar order of magnitude as those for the coronaviruses, implying that in this context SARS-CoV-1 and MERS-CoV were about as difficult to inactivate as influenza $A$. This is a surprising finding, because others have suggested that the UV dose required to inactivate SARS-CoV-2 might be lower than that required to disinfect influenza A (Sagripanti \& Lytle 2020). This is because coronaviruses have genomes that are approximately twice as long as that of influenza A, making them in theory much more vulnerable to damage from UV-C (Sagripanti \& Lytle 2020). Indeed, in a summary collated from hundreds of published studies by Kowalski (Kowalski 2010), the $Z$ values for influenza $A$ in water were reported as being in the range $0.04800-0.13810 \mathrm{~m}^{2} / \mathrm{J}$, much higher than the values achieved by Heimbuch and Harnish (Heimbuch \& Harnish 2019). As such, this suggests that the substrate or medium in which microbes are irradiated plays an important role in influencing the magnitude of the $Z$ value achieved. Indeed, it is well known in other contexts that UV-C light can 
397 be attenuated as it passes through liquids (Mamane 2008). When UV light passes through a

398

399

400

401

402

403

404

405

406

407

408

409

410

411

412

413

414

415

416

417

418

419

420

421

422

423

424

425

426

427

428

429

430

suspension of particles in water, its intensity is reduced due to both scattering and absorption of the light (Gregory 2005). Absorption occurs because the light beam interacts with atoms and molecules in the liquid to raise their energy level, with the result that energy is lost from the beam, whereas scattering occurs when particulates in the fluid interfere with the UV light making it more diffuse (Mamane 2008). Particulates can also shield microbes from UV light. This means that UV inactivation of microbial suspensions in liquid films $>1.2 \mathrm{~mm}$ can be greatly inhibited, due to the low penetration depth of UV light through concentrated suspensions (Cheng et al. 2020). Consequently, when interpreting the $Z$ values for SARS-CoV-1, SARS-CoV-2 and MERS-CoV in Table 3, it is important to view them as being strictly contextual.

With regard to UV irradiation of aerosolised viruses, very few published experimental studies exist, with only three specifically relating to coronaviruses (Buonanno et al. 2020; Walker \& Ko 2007). As a result there is a paucity of good quality data relating to UV-C irradiation of SARSCoV-1, SARS-CoV-2 and MERS-CoV in the air. Consequently, we had to establish whether or not Walker and Ko's (Walker \& Ko 2007) published $Z$ value of $0.377 \mathrm{~m}^{2} / \mathrm{J}$ was valid for SARSCoV-2 in air. Comparison with the $Z$ values presented in Table 3 reveals that this value is considerably greater in magnitude than those achieved for the coronaviruses when they were irradiated in liquid or on equipment substrates. This however, is to be expected given that liquids attenuate UV penetration (Mamane 2008). Also the finding appears to be broadly in keeping with the behaviour of adenoviruses when irradiated in air and in liquid. Furthermore, because Bedell et al. (Bedell et al. 2016) found MERS-CoV to be more susceptible to UV-C damage than MHV coronavirus, this strongly supports the use of Walker and Ko's (Walker \& Ko 2007) $Z$ value for MHV coronavirus as a valid surrogate for SARS-CoV-2 in air. Having said this, because the UV susceptibility of the target microbe is crucial to the performance of any upperroom UVGI installation, our use of Walker and Ko's Z value for the MHV coronavirus to represent SARS-CoV-2 should be treated with caution. For this reason, when we assessed the performance of the upper-room UVGI in our hypothetical room, we used both 0.377 and 0.0377 $\mathrm{m}^{2} / \mathrm{J}$ in our simulations. In so doing, we effectively modelled both the expected and worst-case scenarios.

The results for the expected and worst-case scenarios in Table 7, strongly suggest that upperroom UVGI, if applied correctly, should be effective at disinfecting SARS-CoV-2 virions suspended in respiratory droplets in the air. This finding is of course very much dependent on

Peer] reviewing PDF | (2020:07:51003:1:1:NEW 4 Sep 2020) 
431 the surrogate $Z_{u r}$ value being truly representative for SARS-CoV-2. With respect to this, one

432 limitation of our study is that we did not distinguish between the $Z$ values achieved using a

433 single-pass test rig, such as that used by Walker and Ko (Walker \& Ko 2007), and those

434 achieved in real-life by an upper-room UVGI system. With the latter, because the irradiation

435 process is fragmented, compared with a single-pass system, it is thought that higher UV doses

436 might be required to achieve equivalent levels of inactivation (Beggs et al. 2006; Yang et al.

437 2017). However, while this specifically applies to aerosolised bacteria that can rapidly repair UV

438 damage when the irradiation process becomes fragmented (Beggs 2002), it is not known to

439 what extent this applies to viruses, which are not metabolically active, although it is known that

440 through photoreactivation viruses can repair UV damage (Weinbauer et al. 1997).

441 Notwithstanding this, because the $Z$ values achieved for coronaviruses irradiated in air

442 (Buonanno et al. 2020; Walker \& Ko 2007) are very similar in magnitude to those exhibited by

443 Mycobacterium tuberculosis (the causative agent of TB) in air (i.e. $0.33-0.48 \mathrm{~m}^{2} / \mathrm{J}$ (Riley et al.

444 1976)), there is good reason to believe that upper-room UVGI might be effective at mitigating

445 the spread of COVID-19 indoors.

446

447 Upper-room UVGI air disinfection is highly dependent on good air mixing occurring between the

448 upper and lower portions of the room space (Beggs \& Sleigh 2002; Nicas \& Miller 1999; Noakes

449 et al. 2004; Zhu et al. 2013). In the study presented here we assumed that complete mixing

450 occurred, which although a reasonable approximation in many instances, is not always the case

451 because short circuiting can occur (Beggs \& Sleigh 2002). If the room air mixing factor is low,

452 say for example due stratification in a poorly ventilated space, then this can greatly impair the

453 disinfection performance of an upper-room UVGI system (Beggs \& Sleigh 2002; Noakes et al.

454 2004). It is therefore important when designing such systems to carefully consider the air

455 movement in the room space, in order to eliminate stagnant regions and maximize air

456 movement through the UV field. In the context of COVID-19, this is particularly important

457 because, unlike TB which is spread via the inhalation of droplet nuclei $<5 \mu \mathrm{m}$ in diameter, it is

458 thought that COVID-19 can be transmitted through the exhalation of larger respiratory droplets

$459<100 \mu \mathrm{m}$, which rapidly reduce in size due to evaporation (Beggs 2020; Liu et al. 2017; Xie et al.

4602007 ) to become aerosols, say, $<50 \mu \mathrm{m}$ in diameter (Nicas et al. 2005). These larger aerosol

461 particles have settling velocities $<0.1 \mathrm{~m} / \mathrm{s}$ and as such can readily be transported on convective

462 room air currents, with the result that they can remain suspended in room air for many minutes.

463 However, if the velocities of the convection currents drop, then some of the larger aerosol

464 particles may decouple from the air stream and settle out due to gravitational deposition, 
465

466

467

468

469

470

471

472

473

474

475

476

477

478

479

480

481

482

483

484

485

486

487

488

489

490

491

492

493

494

495

496

497

498

potentially passing through the breathing zone where they can be inhaled by the room occupants. This is particularly the case if the air is poorly mixed and stagnant regions exist within the room space. Under such circumstances larger aerosol particles might be inhaled without being fully irradiated by the upper-room UV field, undermining the effectiveness of the whole UVGI installation. Consequently, if upper-room UVGI is to be effective against COVID-19, it is important to both promote good room air mixing and also ensure that larger aerosol particles (e.g.. $<50 \mu \mathrm{m}$ in diameter) receive the required UV irradiation dose. As such, this may require upper-room UVGI systems to be supplemented with ceiling mounted fans (Zhu et al. 2013) or other devices to promote the necessary air movement to ensure that larger aerosol particles are adequately irradiated.

One major advantage of upper-room UVGI is that it can be retrospectively fitted into buildings provided that the floor to ceiling height is large enough to ensure that the UV field does not impinge on room occupants (First et al. 1999b). By installing such a system it is possible to effectively 'turbo-charge' the efficacy of the ventilation system. Indeed, in keeping with the findings of McDevitt et al. (McDevitt et al. 2008), our analysis suggests that it is possible to achieve $>100$ equivalent $A C / h$ by installing upper-room UVGI. Using equation 9, we can calculate the UV rate constant, $k_{u v}$, which can be thought of as the equivalent air change rate per second. Once known, this in turn can be used, together with the ventilation and particulate deposition rate constants, $k_{v}$, and $k_{d}$, in equation 10 , to compute the concentration of viral partials in the room space at any point in time.

While our analysis has been able to show that upper-room UVGI has the potential to disinfect the SARS-CoV-2 virus when suspended in room air, we are nonetheless conscious of the limitations of the feasibility study. Chief among these is the fact that we had to assume the value of the upper-room UV susceptibility constant, $Z_{u r}$, for SARS-CoV-2. Although the true value of this constant is likely to be similar to that exhibited by other aerosolised coronaviruses, we cannot know its exact magnitude without further experimental work. Consequently, the results of the study should be considered as indicative only. Also, in the study it was assumed that the room air is well mixed, which, as discussed above, may not necessarily be the case in some applications. In particular, because the model used was relatively simple, we were not able to assess how upper-room UVGI might perform in situations where aerosol particles decouple from the air stream due to gravitational deposition, or remain suspended in the breath zone. It is therefore recommended that future studies investigating the use of upper-room UVGI to prevent 
499

500

501

502

503

504

505

506

507

508

509

510

511

\section{2}

513

514

515

516

517

518

519

520

521

522

523

524

525

526

527

528

529

530

531

532

533

534

535

536

537

COVID-19 transmission use computational fluid dynamics (CFD) to assess the limitations of the technology with respect to the disinfection of larger aerosol particles that might decouple from room air convection currents.

\section{Conclusions}

In conclusion, we have been able to demonstrate that the SARS-CoV-2 virus is relatively easily inactivated by UV-C light and that when aerosolised the virus is likely to have a UV susceptibility constant, $Z_{u r}$, that is similar to that exhibited by other coronaviruses in air. This suggests that SARS-CoV-2 when suspended in air should be reasonably easy to inactivate using UV light at $254 \mathrm{~nm}$. As such, upper-room UVGI may have potential as an intervention to inhibit the transmission of COVID-19 in buildings, especially in situations where achieving high ventilation rates might otherwise be impractical.

\section{Conflict of interest}

The authors confirm that they have no conflicts of interest.

(1)

\section{References}

Bedell K, Buchaklian AH, and Perlman S. 2016. Efficacy of an Automated Multiple Emitter Whole-Room Ultraviolet-C Disinfection System Against Coronaviruses MHV and MERSCoV. infection control \& hospital epidemiology 37:598-599.

Beggs CB. 2002. A quantitative method for evaluating the photoreactivation of ultraviolet damaged microorganisms. Photochemical \& Photobiological Sciences 1:431-437.

Beggs CB. 2020. Is there an airborne component to the transmission of COVID-19?: a quantitative analysis study. medRxiv.

Beggs CB, Noakes CJ, Sleigh PA, Fletcher LA, and Kerr KG. 2006. Methodology for determining the susceptibility of airborne microorganisms to irradiation by an upper-room UVGI system. Journal of aerosol science 37:885-902.

Beggs CB, and Sleigh PA. 2002. A quantitative method for evaluating the germicidal effect of upper room UV fields. Journal of aerosol science 33:1681-1699.

Bianco A, Biasin M, Pareschi G, Cavalleri A, Cavatorta C, Fenizia C, Galli P, Lessio L, Lualdi M, and Redaelli E. 2020. UV-C irradiation is highly effective in inactivating and inhibiting SARS-CoV-2 replication. medRxiv.

Buonanno M, Welch D, Shuryak I, and Brenner DJ. 2020. Far-UVC light (222 nm) efficiently and safely inactivates airborne human coronaviruses. Scientific Reports 10:1-8.

Card KJ, Crozier D, Dhawan A, Dinh M, Dolson E, Farrokhian N, Gopalakrishnan V, Ho E, Jagdish T, and King ES. 2020. UV sterilization of personal protective equipment with idle laboratory biosafety cabinets during the Covid-19 pandemic. medRxiv. 
538

539

540

541

542

543

544

545

546

547

548

549

550

551

552

553

554

555

556

557

558

559

560

561

562

563

564

565

566

567

568

569

570

571

572

573

574

575

576

577

578

579

580

581

582

583

584

585

586

587

Cheng Y, Chen H, Basurto LAS, Protasenko VV, Bharadwaj S, Islam M, and Moraru Cl. 2020. Inactivation of Listeria and E. coli by Deep-UV LED: effect of substrate conditions on inactivation kinetics. Scientific Reports 10:1-14.

Chia PY, Coleman KK, Tan YK, Ong SWX, Gum M, Lau SK, Sutjipto S, Lee PH, Young BE, and Milton DK. 2020. Detection of Air and Surface Contamination by Severe Acute Respiratory Syndrome Coronavirus 2 (SARS-CoV-2) in Hospital Rooms of Infected Patients. medRxiv.

Darnell MER, Subbarao K, Feinstone SM, and Taylor DR. 2004. Inactivation of the coronavirus that induces severe acute respiratory syndrome, SARS-CoV. Journal of virological methods 121:85-91.

Darnell MER, and Taylor DR. 2006. Evaluation of inactivation methods for severe acute respiratory syndrome coronavirus in noncellular blood products. Transfusion 46:17701777.

Derraik JGB, Anderson WA, Connelly EA, and Anderson YC. 2020. Rapid evidence summary on SARS-CoV-2 survivorship and disinfection, and a reusable PPE protocol using a double-hit process. medRxiv.

Duan SM, Zhao XS, Wen RF, Huang J-j, Pi GH, Zhang SX, Han J, Bi SL, Ruan L, and Dong Xp. 2003. Stability of SARS coronavirus in human specimens and environment and its sensitivity to heating and UV irradiation. Biomedical and environmental sciences: BES 16:246-255.

Eickmann M, Gravemann U, Handke W, Tolksdorf F, Reichenberg S, Muller TH, and Seltsam A. 2020. Inactivation of three emerging viruses - severe acute respiratory syndrome coronavirus, Crimea-Congo haemorrhagic fever virus and Nipah virus - in platelet concentrates by ultraviolet $\mathrm{C}$ light and in plasma by methylene blue plus visible light. Vox Sanguinis 115:146-151.

Escombe AR, Moore DAJ, Gilman RH, Navincopa M, Ticona E, Mitchell B, Noakes C, Martinez C, Sheen P, and Ramirez R. 2009. Upper-room ultraviolet light and negative air ionization to prevent tuberculosis transmission. PLoS medicine 6.

First MW, Nardell EA, Chaisson W, and Riley R. 1999a. Guidelines for the application of upperroom ultraviolet germicidal irradiation for preventing transmission of airborne contagionPart I: Basic principles. Transactions-American Society of Heating Refrigerating and Air Conditioning Engineers 105:869-876.

First MW, Nardell EA, Chaisson W, and Riley R. 1999b. Guidelines for the application of upperroom ultraviolet irradiation for preventing transmission of airborne contagion: Part II Design and operation guidance. ASHRAE Trans 105:1-10.

Gregory J. 2005. Particles in water: properties and processes: CRC Press.

Guo Z-D, Wang Z-Y, Zhang S-F, Li X, Li L, Li C, Cui Y, Fu R-B, Dong Y-Z, and Chi X-Y. 2020. Aerosol and surface distribution of severe acute respiratory syndrome coronavirus 2 in hospital wards, Wuhan, China, 2020. Emerg Infect Dis 26:10.3201.

Hamzavi IH, Lyons AB, Kohli I, Narla S, Parks-Miller A, Gelfand JM, Lim HW, and Ozog D. 2020. Ultraviolet germicidal irradiation: possible method for respirator disinfection to facilitate reuse during COVID-19 pandemic. Journal of the American Academy of Dermatology 82:1511-1512.

Heimbuch B, and Harnish D. 2019. Research to Mitigate a Shortage of Respiratory Protection Devices During Public Health Emergencies. Applied Research Associates:275.

Inagaki H, Saito A, Sugiyama H, Okabayashi T, and Fujimoto S. 2020. Rapid inactivation of SARS-CoV-2 with Deep-UV LED irradiation. Emerging Microbes \& Infections (Accepted for publication).

Jensen MM. 1964. Inactivation of airborne viruses by ultraviolet irradiation. Appl Environ Microbiol 12:418-420.

Peer) reviewing PDF | (2020:07:51003:1:1:NEW 4 Sep 2020) 
588

589

590

591

592

593

594

595

596

597

598

599

600

601

602

603

604

605

606

607

608

609

610

611

612

613

614

615

616

617

618

619

620

621

622

623

624

625

626

627

628

629

630

631

632

633

634

635

636

637

638

Jiang Y, Wang H, Chen Y, He J, Chen L, Liu Y, Hu X, Li A, Liu S, and Zhang P. 2020. Clinical Data on Hospital Environmental Hygiene Monitoring and Medical Staff Protection during the Coronavirus Disease 2019 Outbreak. medRxiv.

Kariwa H, Fujii N, and Takashima I. 2006. Inactivation of SARS coronavirus by means of povidone-iodine, physical conditions and chemical reagents. Dermatology 212:119-123.

Keil SD, Bowen R, and Marschner S. 2020a. Inactivation of Middle East respiratory syndrome coronavirus (MERS-CoV) in plasma products using a riboflavin-

based and ultraviolet light-based photochemical treatment. Transfusion 56:2948-2952.

Keil SD, Ragan I, Yonemura S, Hartson L, Dart NK, and Bowen R. 2020b. Inactivation of severe acute respiratory syndrome coronavirus 2 in plasma and platelet products using a riboflavin and ultraviolet light-based photochemical treatment. Vox Sanguinis:DOI: 10.1111/vox.12937.

Kowalski W. 2010. Ultraviolet germicidal irradiation handbook: UVGI for air and surface disinfection: Springer science \& business media.

Kowalski W, Bahnfleth WP, Witham DL, Severin BF, and Whittam TS. 2000. Mathematical modeling of ultraviolet germicidal irradiation for air disinfection. Quantitative microbiology 2:249-270.

Liu L, Wei J, Li Y, and Ooi A. 2017. Evaporation and dispersion of respiratory droplets from coughing. Indoor Air 27:179-190.

Mamane H. 2008. Impact of particles on UV disinfection of water and wastewater effluents: a review. Reviews in Chemical Engineering 24:67-157.

McDevitt JJ, Lai KM, Rudnick SN, Houseman EA, First MW, and Milton DK. 2007. Characterization of UVC light sensitivity of vaccinia virus. Appl Environ Microbiol 73:5760-5766.

McDevitt JJ, Milton DK, Rudnick SN, and First MW. 2008. Inactivation of poxviruses by upperroom UVC light in a simulated hospital room environment. PLoS One 3:e3186.

McDevitt JJ, Rudnick SN, and Radonovich LJ. 2012. Aerosol susceptibility of influenza virus to UV-C light. Appl Environ Microbiol 78:1666-1669.

Miller SL, Nazaroff WW, Jimenez JL, Boerstra A, Buonanno G, Dancer SJ, Kurnitski J, Marr LC, Morawska L, and Noakes C. 2020. Transmission of SARS-CoV-2 by inhalation of respiratory aerosol in the Skagit Valley Chorale superspreading event. medRxiv.

Morawska L, Tang JW, Bahnfleth W, Bluyssen PM, Boerstra A, Buonanno G, Cao J, Dancer S, Floto A, and Franchimon F. 2020. How can airborne transmission of COVID-19 indoors be minimised? Environment International: 105832.

Mphaphlele M, Dharmadhikari AS, Jensen PA, Rudnick SN, Van Reenen TH, Pagano MA, Leuschner W, Sears TA, Milonova SP, and van der Walt M. 2015. Institutional Tuberculosis Transmission. Controlled trial of upper room ultraviolet air disinfection: a basis for new dosing guidelines. American journal of respiratory and critical care medicine 192:477-484.

Nardell E, and Nathavitharana R. 2019. Air disinfection in measles transmission hotspots. The Lancet 394:1009-1010.

Nardell EA, and Nathavitharana RR. 2020. Airborne spread of SARS-CoV-2 and a potential role for air disinfection. Jama 324:141-142.

Nicas M, and Miller SL. 1999. A multi-zone model evaluation of the efficacy of upper-room air ultraviolet germicidal irradiation. Applied Occupational and Environmental Hygiene 14:317-328.

Nicas M, Nazaroff WW, and Hubbard A. 2005. Toward understanding the risk of secondary airborne infection: emission of respirable pathogens. J Occup Environ Hyg 2:143-154.

Noakes CJ, Beggs CB, and Sleigh PA. 2004. Effect of room mixing and ventilation strategy on the performance of upper room ultraviolet germicidal irradiation systems. Proceedings of ASHRAE IAQ 2004:1-13.

PeerJ reviewing PDF | (2020:07:51003:1:1:NEW 4 Sep 2020) 
639 Noakes CJ, Khan MAI, and Gilkeson CA. 2015. Modeling infection risk and energy use of

640

641

642

643

644

645

646

647

648

649

650

651

652

653

654

655

656

657

658

659

660

661

662

663

664

665

666

667

668

669

670

671

672

673

674

675

676

677

678

679

680

681

682

683

684

685

686

687

688

689 upper-room Ultraviolet Germicidal Irradiation systems in multi-room environments. Science and Technology for the Built Environment 21:99-111.

Ragan I, Hartson L, Pidcoke H, Bowen R, and Goodrich RP. 2020. Pathogen Reduction Of SARS-CoV-2 Virus In Plasma And Whole Blood Using Riboflavin And UV Light. PLoS One 15(5): e0233947.

Riley RL, Knight M, and Middlebrook G. 1976. Ultraviolet susceptibility of BCG and virulent tubercle bacilli. American Review of Respiratory Disease 113:413-418.

Sagripanti J-L, and Lytle CD. 2020. Estimated Inactivation of Coronaviruses by Solar Radiation With Special Reference to COVID-19. Photochemistry and Photobiology 96:731-737.

Santarpia JL, Rivera DN, Herrera V, Morwitzer MJ, Creager H, Santarpia GW, Crown KK, BrettMajor D, Schnaubelt E, and Broadhurst MJ. 2020. Transmission potential of SARS-CoV2 in viral shedding observed at the University of Nebraska Medical Center. medRxiv.

Signify. 2020. Signify and Boston University validate effectiveness of Signify's UV-C light sources on inactivating the virus that causes COVID-19.

Skorzewska N. 2020. A clinician's view from the frontline: UV light and other strategies to reduce aerosol transmission of COVID-19 and protect health workers. Global Biosecurity 1.

Stadnytskyi V, Bax CE, Bax A, and Anfinrud P. 2020. The airborne lifetime of small speech droplets and their potential importance in SARS-CoV-2 transmission. Proceedings of the National Academy of Sciences 117:11875-11877.

Walker CM, and Ko G. 2007. Effect of ultraviolet germicidal irradiation on viral aerosols. Environmental science \& technology 41:5460-5465.

Weinbauer MG, Wilhelm SW, Suttle CA, and Garza DR. 1997. Photoreactivation compensates for UV damage and restores infectivity to natural marine virus communities. Appl Environ Microbiol 63:2200-2205.

Xie X, Li Y, Chwang AT, Ho PL, and Seto WH. 2007. How far droplets can move in indoor environments--revisiting the Wells evaporation-falling curve. Indoor Air 17:211-225.

Yang Y, Lai ACK, Kong RYC, and Deng Q. 2017. Experimental and numerical study of the performance of upper-room ultraviolet germicidal irradiation with the effective Z-value of airborne bacteria. Aerosol Science and Technology 51:1123-1134.

Zhu S, Srebric J, Rudnick SN, Vincent RL, and Nardell EA. 2013. Numerical investigation of upper-room UVGI disinfection efficacy in an environmental chamber with a ceiling fan. Photochemistry and Photobiology 89:782-791.

\footnotetext{
PeerJ reviewing PDF | (2020:07:51003:1:1:NEW 4 Sep 2020)
} 
690

691

692

693

694

695

696

697

698

699

700

701

702 


\section{Table 1 (on next page)}

UV-C doses applied and log reductions achieved in various studies relating to the SARSCoV-1 and MERS-CoV viruses.

* Estimated from plots and data presented in source material. $\mathrm{nr}$ - not reported in source material. 
1 Table 1. UV-C and deep-UV doses applied and log reductions achieved in various studies

2 relating to the SARS-CoV-1, MERS-CoV and SARS-CoV-2 viruses.

\begin{tabular}{|c|c|c|c|c|c|c|c|}
\hline Virus & $\begin{array}{l}\text { UV wave } \\
\text { length } \\
(\mathrm{nm})\end{array}$ & $\begin{array}{l}\text { Medium \& } \\
\text { context }\end{array}$ & $\begin{array}{l}\text { Irradianc } \\
\mathrm{e} \\
\left(\mu \mathrm{W} / \mathrm{cm}^{2}\right. \\
)\end{array}$ & $\begin{array}{l}\text { Duratio } \\
\mathrm{n} \\
(\mathrm{min} \& \\
\mathrm{sec})\end{array}$ & $\begin{array}{l}\text { UV Dose } \\
\left(\mathrm{mJ} / \mathrm{cm}^{2}\right)\end{array}$ & $\begin{array}{l}\text { Inactivation } \\
\text { (log } \\
\text { reduction) }\end{array}$ & Reference \\
\hline SARS-CoV-1 & UV-C (nr) & $\begin{array}{l}\text { Liquid in well } \\
\text { plate }\end{array}$ & $>90$ & $15 \mathrm{~min}$ & $>81$ & $>\log 0.602$ & Duan et al. [36] \\
\hline SARS-CoV-1 & 254 & $\begin{array}{l}\text { Liquid in well } \\
\text { plate }\end{array}$ & 4016 & $1 \mathrm{~min}$ & 241 & $\log 1.4^{*}$ & Darnell et al. [34] \\
\hline SARS-CoV-1 & 254 & $\begin{array}{l}\text { Liquid in well } \\
\text { plate }\end{array}$ & 4016 & $6 \min$ & 1446 & $\log 4.5^{*}$ & Darnell et al. [34] \\
\hline SARS-CoV-1 & 254 & $\begin{array}{l}\text { Liguid in well } \\
\text { plate }\end{array}$ & 4016 & $20 \mathrm{~min}$ & 4819 & $\log 4.1^{*}$ & $\begin{array}{l}\text { Darnell \& Taylor } \\
\text { [35] }\end{array}$ \\
\hline SARS-CoV-1 & UV-C (nr) & $\begin{array}{l}\text { Liquid in well } \\
\text { plate }\end{array}$ & 134 & $5 \mathrm{~min}$ & 40 & $\log 3.2^{*}$ & Kariwa et al. [27] \\
\hline SARS-CoV-1 & UV-C (nr) & $\begin{array}{l}\text { Liquid in well } \\
\text { plate }\end{array}$ & 134 & $15 \mathrm{~min}$ & 121 & $\log 5.325$ & Kariwa et al. [27] \\
\hline SARS-CoV-1 & 254 & $\begin{array}{l}\text { Respirator } \\
\text { surface }\end{array}$ & 2300 & $\begin{array}{l}7.25 \\
\min \end{array}$ & 1000 & $\geq \log 4.81$ & $\begin{array}{l}\text { Heimbuch \& } \\
\text { Harnish [4] }\end{array}$ \\
\hline SARS-CoV-1 & 254 & $\begin{array}{l}\text { Platelet } \\
\text { concentrates }\end{array}$ & $\mathrm{nr}$ & $\mathrm{nr}$ & 50 & $\log 3.05$ & Eickmann et al. [3] \\
\hline SARS-CoV-1 & 254 & $\begin{array}{l}\text { Platelet } \\
\text { concentrates }\end{array}$ & $\mathrm{nr}$ & $\mathrm{nr}$ & 100 & $\geq \log 3.5$ & Eickmann et al. [3] \\
\hline MERS-CoV & 254 & $\begin{array}{l}\text { Respirator } \\
\text { surface }\end{array}$ & 2300 & $\begin{array}{l}7.25 \\
\min \end{array}$ & 1000 & $\geq \log 4.5$ & $\begin{array}{l}\text { Heimbuch \& } \\
\text { Harnish [4] }\end{array}$ \\
\hline MERS-CoV & UV-C (nr) & $\begin{array}{l}\text { Droplet on glass } \\
\text { slip }\end{array}$ & $\mathrm{nr}$ & $5 \min$ & $\mathrm{nr}$ & $\geq \log 5.91$ & Bedell et al. [37] \\
\hline SARS-CoV-2 & 254 & $\begin{array}{l}\text { Liguid in well } \\
\text { plate }\end{array}$ & 1082 & $\mathrm{nr}$ & 3.7 & $\log 3.3$ & Bianco et al. [38] \\
\hline SARS-CoV-2 & UV-C (nr) & $\begin{array}{l}\text { Inoculated } \\
\text { material }\end{array}$ & $\mathrm{nr}$ & $6 \mathrm{sec}$ & 5.0 & $\log 2.0$ & Signify [39] \\
\hline SARS-CoV-2 & UV-C (nr) & $\begin{array}{l}\text { Inoculated } \\
\text { material }\end{array}$ & $\mathrm{nr}$ & $25 \mathrm{sec}$ & 22.0 & $\log 6.0$ & Signify [39] \\
\hline SARS-CoV-2 & 280 & $\begin{array}{l}\text { Liquid in petri } \\
\text { dish }\end{array}$ & 3750 & $1 \mathrm{sec}$ & 3.75 & $\log 0.9$ & Inagaki et al. [40] \\
\hline SARS-CoV-2 & 280 & $\begin{array}{l}\text { Liquid in petri } \\
\text { dish }\end{array}$ & 3750 & $10 \mathrm{sec}$ & 37.5 & $\log 3.0$ & Inagaki et al. [40] \\
\hline
\end{tabular}

$3 \quad$ * Estimated from plots and data presented in source material.

4 Legend: $\mathrm{nr}$ - not reported in source material. 


\section{Table 2 (on next page)}

UV-A/B doses applied and log reductions achieved in the various studies relating to the disinfection of SARS-CoV-2 and MERS-CoV in blood products when riboflavin is used.

$\mathrm{nr}$ - not reported in source material 
1 Table 2. UV-A/B doses applied and log reductions achieved in the various studies relating to the

2 disinfection of SARS-CoV-2 and MERS-CoV in blood products when riboflavin is used.

\begin{tabular}{|l|l|l|l|l|l|l|l|}
\hline Virus & $\begin{array}{l}\text { UV } \\
\text { wave } \\
\text { length } \\
(\mathrm{nm})\end{array}$ & $\begin{array}{l}\text { Medium \& } \\
\text { context }\end{array}$ & $\begin{array}{l}\text { Irradianc } \\
\mathrm{e} \\
\left(\mu \mathrm{W} / \mathrm{cm}^{2}\right. \\
)\end{array}$ & $\begin{array}{l}\text { Duratio } \\
\mathrm{n} \\
(\mathrm{min})\end{array}$ & $\begin{array}{l}\text { UV Dose } \\
(\mathrm{mJ} / \mathrm{mL})\end{array}$ & $\begin{array}{l}\text { Inactivation } \\
\text { (log } \\
\text { reduction) }\end{array}$ & Reference \\
\hline MERS-CoV & $\begin{array}{l}270- \\
360\end{array}$ & $\begin{array}{l}\text { Blood plasma + } \\
\text { riboflavin } \\
\text { (pooled) }\end{array}$ & $\mathrm{nr}$ & $\mathrm{nr}$ & 6240 & $\geq \log 4.07$ & Keil et al. [41] \\
\hline MERS-CoV & $\begin{array}{l}270- \\
360\end{array}$ & $\begin{array}{l}\text { Blood plasma + } \\
\text { riboflavin (single } \\
\text { donor) }\end{array}$ & $\mathrm{nr}$ & $\mathrm{nr}$ & 6240 & $\geq \log 4.42$ & Keil et al. [41] \\
\hline SARS-CoV-2 & $\begin{array}{l}270- \\
360\end{array}$ & $\begin{array}{l}\text { Blood plasma + } \\
\text { riboflavin }\end{array}$ & $\mathrm{nr}$ & 4 & 1872 & $\geq \log 2.61$ & Ragan et al. [1] \\
\hline SARS-CoV-2 & $\begin{array}{l}270- \\
360\end{array}$ & $\begin{array}{l}\text { Blood plasma + } \\
\text { riboflavin }\end{array}$ & $\mathrm{nr}$ & 4 & 3744 & $\geq \log 4.72$ & Ragan et al. [1] \\
\hline SARS-CoV-2 & $270-$ & $\begin{array}{l}\text { Blood plasma + } \\
\text { riboflavin }\end{array}$ & $\mathrm{nr}$ & $\mathrm{nr}$ & 6240 & $\geq \log 3.4$ & Keil et al. [2] \\
\hline SARS-CoV-2 & $\begin{array}{l}270- \\
360\end{array}$ & $\begin{array}{l}\text { Platelets }+ \\
\text { riboflavin }\end{array}$ & $\mathrm{nr}$ & $\mathrm{nr}$ & 6240 & $\geq \log 4.53$ & Keil et al. [2] \\
\hline
\end{tabular}

3 Legend: $\mathrm{nr}$ - not reported in source material.

4 


\section{Table 3(on next page)}

Calculated $Z$ values for the UV-C irradiation experiments.

* Estimated from plots and data presented in source material. 
1 Table 3. Calculated $Z$ values for the UV-C and deep-UV irradiation experiments.

\begin{tabular}{|c|c|c|c|c|}
\hline Virus & $\begin{array}{l}\text { UV Dose } \\
\left(\mathrm{mJ} / \mathrm{cm}^{2}\right)\end{array}$ & $\begin{array}{l}\text { Inactivation } \\
\text { (log reduction) }\end{array}$ & $\begin{array}{l}\text { UV } \\
\text { susceptibility } \\
\text { constant, Z } \\
\left(\mathrm{m}^{2} / \mathrm{J}\right)\end{array}$ & Reference \\
\hline SARS-CoV-1 & $>81$ & $>\log 0.602$ & 0.00171 & Duan et al. [36] \\
\hline SARS-CoV-1 & 241 & $\log 1.4^{*}$ & $0.00134^{*}$ & Darnell et al. [34] \\
\hline SARS-CoV-1 & 1446 & $\log 4.5^{*}$ & $0.00072^{*}$ & Darnell et al. [34] \\
\hline SARS-CoV-1 & 4819 & $\log 4.1^{*}$ & $0.00020^{*}$ & Darnell \& Taylor [35] \\
\hline SARS-CoV-1 & 40 & $\log 3.2^{*}$ & $0.01833^{*}$ & Kariwa et al. [27] \\
\hline SARS-CoV-1 & 121 & $\log 5.325$ & 0.01017 & Kariwa et al. [27] \\
\hline SARS-CoV-1 & 1000 & $\geq \log 4.81$ & 0.00111 & $\begin{array}{l}\text { Heimbuch \& Harnish } \\
\text { [4] }\end{array}$ \\
\hline SARS-CoV-1 & 50 & $\log 3.05$ & 0.01405 & Eickmann et al. [3] \\
\hline SARS-CoV-1 & 100 & $\geq \log 3.5$ & 0.00806 & Eickmann et al. [3] \\
\hline MERS-CoV & 1000 & $\geq \log 4.5$ & 0.00104 & $\begin{array}{l}\text { Heimbuch \& Harnish } \\
\text { [4] }\end{array}$ \\
\hline SARS-CoV-2 & 3.7 & $\log 3.3$ & 0.20536 & Bianco et al. [38] \\
\hline SARS-CoV-2 & 5 & $\log 2.0$ & 0.09210 & Signify [39] \\
\hline SARS-CoV-2 & 22 & $\log 6.0$ & 0.06280 & Signify [39] \\
\hline SARS-CoV-2 & $3.75^{\star *}$ & $\log 0.9$ & 0.05526 & Inagaki et al. [40] \\
\hline SARS-CoV-2 & $37.5^{\star \star}$ & $\log 3.0$ & 0.01842 & Inagaki et al. [40] \\
\hline
\end{tabular}

* Estimated from plots and data presented in source material.

$3{ }^{* *}$ Using deep-UV light at $222 \mathrm{~nm}$. 
Table 4 (on next page)

Calculated $Z$ values for the UV-A/B irradiation plus riboflavin experiments. 
1 Table 4. Calculated $Z$ values for the UV-A/B irradiation plus riboflavin experiments.

\begin{tabular}{|l|l|l|l|l|}
\hline Virus & $\begin{array}{l}\text { UV Dose } \\
(\mathrm{mJ} / \mathrm{mL})\end{array}$ & $\begin{array}{l}\text { Inactivation } \\
\text { (log reduction) }\end{array}$ & $\begin{array}{l}\text { UV } \\
\text { susceptibility } \\
\text { constant , Z } \\
\left(\mathrm{m}^{2} / \mathrm{J}\right)\end{array}$ & Reference \\
\hline MERS-CoV & 6240 & $\geq \log 4.07$ & 0.00015 & Keil et al. [41] \\
\hline MERS-CoV & 6240 & $\geq \log 4.42$ & 0.00016 & Keil et al. [41] \\
\hline SARS-CoV-2 & 1872 & $\geq \log 2.61$ & 0.00032 & Ragan et al. [1] \\
\hline SARS-CoV-2 & 3744 & $\geq \log 4.72$ & 0.00029 & Ragan et al. [1] \\
\hline SARS-CoV-2 & 6240 & $\geq \log 3.4$ & 0.00013 & Keil et al. [2] \\
\hline SARS-CoV-2 & 6240 & $\geq \log 4.53$ & 0.00017 & Keil et al. [2] \\
\hline
\end{tabular}

2 


\section{Table 5 (on next page)}

Calculated $Z$ values for the UV-C irradiation experiments for different strains of influenza A tested by Heimbuch \& Harnish 
1 Table 5. Calculated $Z$ values for the UV-C irradiation experiments for different strains of

2 influenza A tested by Heimbuch \& Harnish [4].

\begin{tabular}{|l|l|l|l|l|}
\hline Virus & $\begin{array}{l}\text { Medium \& } \\
\text { context }\end{array}$ & $\begin{array}{l}\text { UV Dose } \\
\left(\mathrm{mJ} / \mathrm{cm}^{2}\right)\end{array}$ & $\begin{array}{l}\text { Inactivation } \\
\text { (log reduction) }\end{array}$ & $\begin{array}{l}\text { UV } \\
\text { susceptibility } \\
\text { constant , Z } \\
\left(\mathrm{m}^{2} / \mathrm{J}\right)\end{array}$ \\
\hline $\begin{array}{l}\text { Influenza A } \\
\text { (H1N1) }\end{array}$ & $\begin{array}{l}\text { Respirator } \\
\text { surface }\end{array}$ & 1000 & $\geq \log 6.01$ & 0.00138 \\
\hline $\begin{array}{l}\text { Avian influenza A } \\
\text { (H5N1) }\end{array}$ & $\begin{array}{l}\text { Respirator } \\
\text { surface }\end{array}$ & 1000 & $\geq \log 4.46$ & 0.00103 \\
\hline $\begin{array}{l}\text { Influenza A } \\
\text { (H7N9), } \\
\text { A/Anhui/1/2013 } \\
\text { strain }\end{array}$ & $\begin{array}{l}\text { Respirator } \\
\text { surface }\end{array}$ & 1000 & $\geq \log 5.15$ & 0.00119 \\
\hline $\begin{array}{l}\text { Influenza A } \\
\text { (H7N9), } \\
\text { A/Shanghai/1/201 } \\
3\end{array}$ & $\begin{array}{l}\text { Respirator } \\
\text { surface }\end{array}$ & 1000 & $\geq \log 5.31$ & 0.00122 \\
\hline
\end{tabular}

3

4 
Table 6(on next page)

Summary of reported effective $Z$ values for single-pass UV irradiation experiments performed on aerosolised viruses in air. 
1 Table 6. Summary of reported effective $Z$ values for single-pass UV-C irradiation experiments 2 performed on selected aerosolised viruses in air.

\begin{tabular}{|c|c|c|c|c|}
\hline Researchers & Virus & $\begin{array}{l}\text { UV-C } \\
\text { wavelength }\end{array}$ & $\begin{array}{l}\text { Effective } Z \\
\text { value } \\
\left(\mathrm{m}^{2} / \mathrm{J}\right)\end{array}$ & Reporter \\
\hline Jensen [33] & Adenovirus & $254 \mathrm{~nm}$ & 0.0546 & $\begin{array}{l}\text { Kowalski et al. } \\
\text { [32] }\end{array}$ \\
\hline Jensen [33] & Coxsackie B-1 & $254 \mathrm{~nm}$ & 0.1108 & $\begin{array}{l}\text { Kowalski et al. } \\
\text { [32] }\end{array}$ \\
\hline Jensen [33] & Influenza A & $254 \mathrm{~nm}$ & 0.1187 & $\begin{array}{l}\text { Kowalski et al. } \\
\text { [32] }\end{array}$ \\
\hline Jensen [33] & Sindbis virus & $254 \mathrm{~nm}$ & 0.1040 & Kowalski [30] \\
\hline Jensen [33] & Vaccinia virus & $254 \mathrm{~nm}$ & 0.1528 & $\begin{array}{l}\text { Kowalski et al. } \\
\text { [32] }\end{array}$ \\
\hline Walker \& Ko [31] & Adenovirus & $254 \mathrm{~nm}$ & 0.0390 & Walker \& Ko [31] \\
\hline Walker \& Ko [31] & MHV coronavirus & $254 \mathrm{~nm}$ & 0.3770 & Walker \& Ko [31] \\
\hline $\begin{array}{l}\text { McDevitt et al. } \\
\text { [26] }\end{array}$ & Influenza A & $254 \mathrm{~nm}$ & 0.2700 & $\begin{array}{l}\text { McDevitt et al. } \\
{[26]}\end{array}$ \\
\hline $\begin{array}{l}\text { McDevitt et al. } \\
\text { [55] }\end{array}$ & Vaccinia virus & $254 \mathrm{~nm}$ & 2.5400 & $\begin{array}{l}\text { McDevitt et al. } \\
\text { [55] }\end{array}$ \\
\hline $\begin{array}{l}\text { Buonanno et al. } \\
{[42]}\end{array}$ & $\begin{array}{l}\text { Human coronavirus } \\
229 \mathrm{E}\end{array}$ & $222 \mathrm{~nm}$ & 0.4100 & $\begin{array}{l}\text { Buonanno et al. } \\
{[42]}\end{array}$ \\
\hline $\begin{array}{l}\text { Buonanno et al. } \\
{[42]}\end{array}$ & $\begin{array}{l}\text { Human coronavirus } \\
\text { OC43 }\end{array}$ & $222 \mathrm{~nm}$ & 0.5900 & $\begin{array}{l}\text { Buonanno et al. } \\
{[42]}\end{array}$ \\
\hline
\end{tabular}

3

4 


\section{Table 7 (on next page)}

Predicted average upper-room UV irradiance fluxes required to achieve $50 \%, 70 \%$ and $90 \%$ inactivation for SARS-CoV-2 assuming a range of $Z_{u r}$ values and ventilation rates.

(Assuming $Z_{u r}=0.377$ or $0.0377 \mathrm{~m}^{2} \mathrm{~J}$ ) 
1 Table 7. Predicted average upper-room UV irradiance fluxes required to achieve $50 \%, 70 \%$ and $290 \%$ inactivation for SARS-CoV-2 assuming a range of $Z_{u r}$ values and ventilation rates.

3 (Assuming $Z_{u r}=0.377$ or $0.0377 \mathrm{~m}^{2} / \mathrm{J}$ )

\begin{tabular}{|c|c|c|c|c|c|}
\hline $\begin{array}{l}\text { Ventilation rate } \\
(\mathrm{AC} / \mathrm{h})\end{array}$ & $\begin{array}{l}\text { Average } \\
\text { particle } \\
\text { residence } \\
\text { time in UV } \\
\text { field. } \\
\text { (mins.) }\end{array}$ & $\begin{array}{l}\text { UV } \\
\text { susceptibilit } \\
\text { y constant } \\
Z_{\text {ur }} \\
\left(\mathrm{m}^{2} / \mathrm{J}\right)\end{array}$ & \begin{tabular}{|l} 
Average \\
irradiance \\
required for \\
$50 \%$ \\
inactivation \\
$\left(\mu \mathrm{W} / \mathrm{cm}^{2}\right)$
\end{tabular} & $\begin{array}{l}\text { Average } \\
\text { irradiance } \\
\text { required for } \\
70 \% \\
\text { inactivation } \\
\left(\mu \mathrm{W} / \mathrm{cm}^{2}\right)\end{array}$ & $\begin{array}{l}\text { Average } \\
\text { irradiance } \\
\text { required for } \\
90 \% \\
\text { inactivation } \\
\left(\mu \mathrm{W} / \mathrm{cm}^{2}\right)\end{array}$ \\
\hline 1 & 9.6 & 0.3770 & 0.319 & 0.554 & 1.060 \\
\hline 2 & 4.8 & 0.3770 & \begin{tabular}{|l|}
0.638 \\
\end{tabular} & 1.109 & 2.121 \\
\hline 4 & 2.4 & 0.3770 & 1.277 & 2.218 & 4.241 \\
\hline 6 & 1.6 & 0.3770 & 1.915 & 3.327 & 6.362 \\
\hline 8 & 1.2 & 0.3770 & 2.554 & 4.436 & 8.482 \\
\hline 1 & 9.6 & 0.0377 & 3.192 & 5.544 & 10.604 \\
\hline 2 & 4.8 & 0.0377 & 6.384 & 11.088 & 21.207 \\
\hline 4 & 2.4 & 0.0377 & 12.768 & 22.177 & 42.414 \\
\hline 6 & 1.6 & 0.0377 & 19.152 & 33.266 & 63.621 \\
\hline 8 & 1.2 & 0.0377 & 25.536 & 44.355 & 84.829 \\
\hline
\end{tabular}

4 
Figure 1

An upper-room UVGI installation.

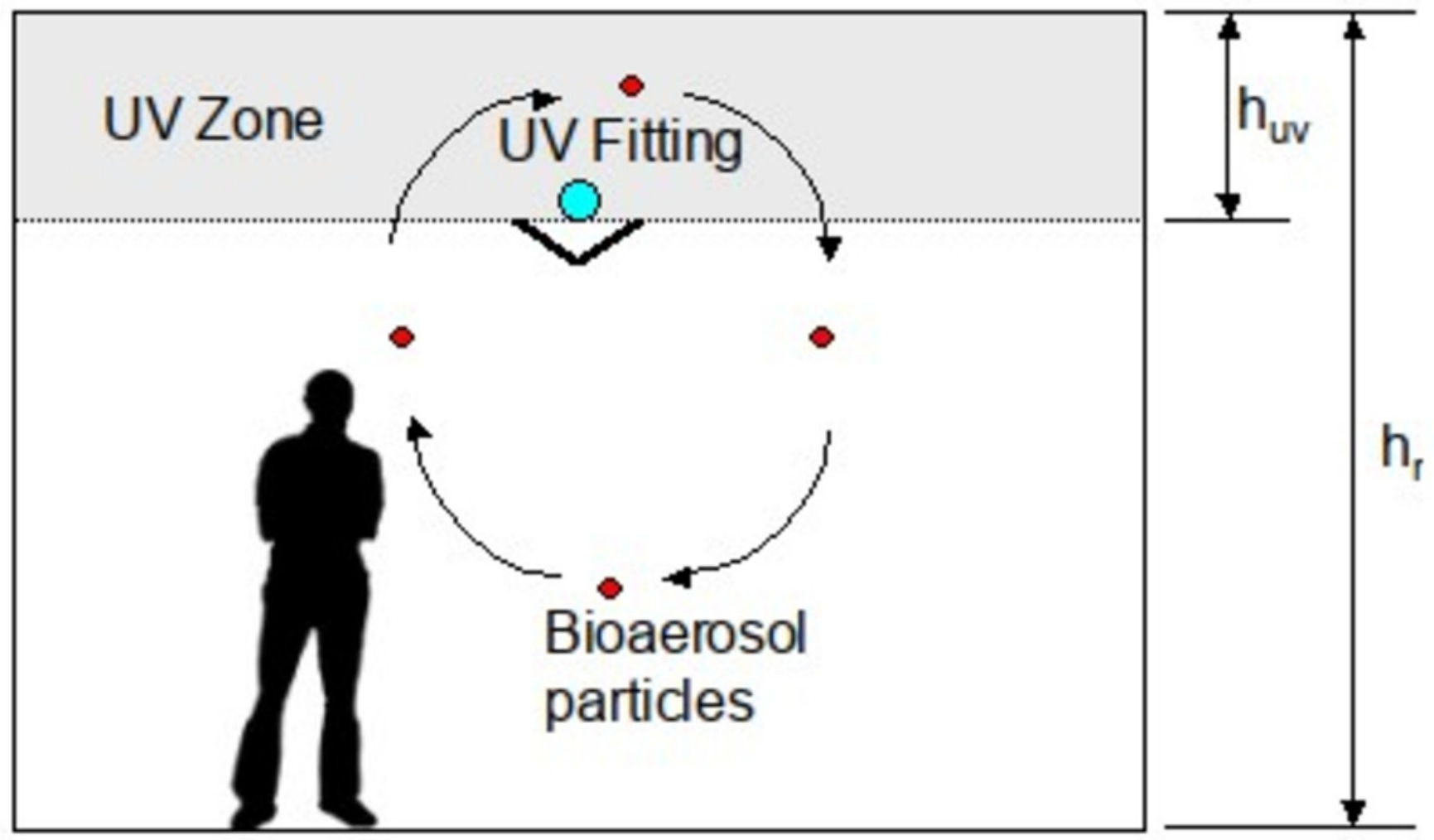

